\section{Cartografia interativa: jogo digital para a alfabetização cartográfica em São Pedro do Sul/RS}

Resumo: A presente pesquisa teve como objetivo geral elaborar um jogo digital capaz de auxiliar no processo de alfabetização cartográfica e validá-lo com os sujeitos do ensino e aprendizagem da Geografia. Para tanto, primeiramente realizou-se um aprofundamento nas questões teórico-metodológicas por meio do resgate teórico. Definidas as matrizes teóricas deu-se início a elaboração do jogo digital. A validação do jogo ocorreu com alunos da quinta série da Escola Estadual de Educação Básica Tito Ferrari, localizada no município de São Pedro do Sul/RS. Como resultados apontam-se a elaboração e validação do jogo "Pedrinho em: conhecendo o mapa" que propiciou uma aprendizagem significativa da alfabetização cartográfica e forneceu um importante recurso didático para o Município.

\section{Interactive cartographic: digital game for cartographic literacy in São Pedro do Sul/rs}

Abstract: The current research have aimed how to develop a digital game able to assist in the process of cartographic literacy and validate with the subjects of theaching and learning Geography. To do so, first held in a deepening theoretical and methodological issues through restoring theoretical. Having the theoretical mold defined the development of the digital game begun. The game's validation has occurred with fifth grade students from Escola Estadual de Educação Básica Tito Ferrari located in São Pedro do Sul/RS. As results we achieved the game's elaboration and validate "Pedrinho in: knowing the map" wich provided a meaningful cartographic learning literacy and important educational resource for the city.
Gabriela Dambros*

Franciele Francisca Marmentini Rovani*

João Henrique Quoos*

Roberto Cassol**

* Mestrandos do Programa de Pós-Graduação em Geografia da Universidade Federal de Santa Maria.

** Professor do Departamento de Geociências da Universidade Federal de Santa Maria.

Palavras- chave: Jogo digital; Alfabetização Cartográfica; São Pedro do Sul/RS.

Key-Words: Digital game; Cartographic Literacy; São Pedro do Sul/RS. 


\section{Introdução}

As Tecnologias da Informação e Comunicação (TICs) estão cada vez mais integrando o mundo em redes globais e oferecem novas possibilidades à educação, como o compartilhamento de informações, a interatividade e a interdisciplinaridade. A escola não pode ficar alheia a influência e a necessidade de inserção de TICs na prática pedagógica, devendo assim (re)pensar em novas formas de ensino e aprendizagem que contemplem o atual estágio de desenvolvimento tecnológico.

A Ciência Geográfica, no contexto escolar, objetiva trabalhar com os educandos a leitura do mundo, privilegiando a interface sociedade-natureza, uma vez que o espaço geográfico constitui-se em um produto histórico, fruto das inúmeras transformações ocorridas ao longo do tempo. Portanto, pensar no papel da Geografia Escolar é procurar destacar a sua função alfabetizadora resgatando seu objeto de estudo: o espaço. É inseri-lo em uma perspectiva interdisciplinar, na qual a Geografia dialoga com outras áreas do conhecimento articulando a leitura das palavras à leitura do mundo.

Como o espaço é uma construção social e histórica da ação humana é importante que os educandos façam uma leitura crítica dessa realidade entendendo a (re)organização espacial e as dinâmicas próprias do atual estágio da globalização. Assim, salienta-se a importância do conhecimento cartográfico para a localização e representação dos diversos fenômenos. Ao conhecer e entender a forma como o espaço se organiza a partir da leitura de um mapa, o aluno pode adquirir um olhar crítico frente à realidade, obtendo autonomia no pensar e tornando-se agente transformador do seu ambiente de vivência.

Esse processo se inicia com o reconhecimento do espaço vivido, podendo alcançar um nível de abstração maior, permitindo reconhecer e construir o espaço através das representações cartográficas.

Para tanto, pode-se inferir conforme Castrogiovanni (2008) que um educando só conseguirá ler o espaço e aprender a decodificar os elementos necessários para a localização e representação, se for alfabetizado cartograficamente.

No que se refere à inserção das tecnologias na prática pedagógica de Geografia, destaca-se que a aplicação de jogos representa ultrapassar as barreiras do ato de jogar apenas como diversão, utilizando-os como ferramentas de aprendizagem. Tal fato permite a articulação de conhecimentos tecnológicos e geográficos de forma lúdica e interativa, buscando a relação entre o ensino e a aprendizagem significativa.

Nesse contexto, 0 presente trabalho justifica-se pela necessidade de promover nas escolas uma prática pedagógica de Geografia mediada por TICs, na qual os sujeitos da educação apropriam-se de recursos tecnológicos para colocá-los a serviço da formação de um aluno/cidadão consciente, crítico e autônomo. $\mathrm{E}$, também porque o processo de alfabetização cartográfica constitui-se no momento em que devem ser consolidados alguns conceitos cartográficos que serão complementados e aprofundados no decorrer da vida escolar do educando.

Para Almeida; Passini (2002) preparar o aluno para a leitura de mapas deve passar por preocupações metodológicas tão sérias quanto a de ensinar a ler e escrever e a fazer cálculos matemáticos. Concordando com esta idéia, Carrière (1999, p. 2) destaca que "a leitura de mapas é, primeiro de tudo, um conhecimento da linguagem cartográfica". Além disso, enfatiza que o conhecimento é obtido por meio do processo cognitivo no qual os alunos precisam participar e estar cientes deste processo de aprendizagem para que desenvolvam habilidades específicas de leitura de mapas.

Alguns autores consideram também a utilização da terminologia "iniciação cartográfica".

Geografia Ensino \& Pesquisa, v. 16, n.2 p. 183 - 199, maio/ago. 2012

Cartografia interativa: jogo digital para a alfabetização cartográfica em São Pedro do Sul/RS

184

ISSN 2236-4994
De acordo com Soares; Kurkdjian e Mantovani (2000) é importante que a iniciação cartográfica seja desenvolvida desde os primeiros anos escolares. As autoras destacam ainda que a aquisição e a noção de espaço é um processo complexo e progressivo que não é requerido somente no entendimento de temas de geografia e cartografia, mas que está inserida em todos os campos de conhecimento. 
Nessa perspectiva, o presente trabalho teve como problemática central a elaboração de um jogo digital cartográfico e sua validação na rede pública de ensino do município de São Pedro do Sul/RS (Figura 01).

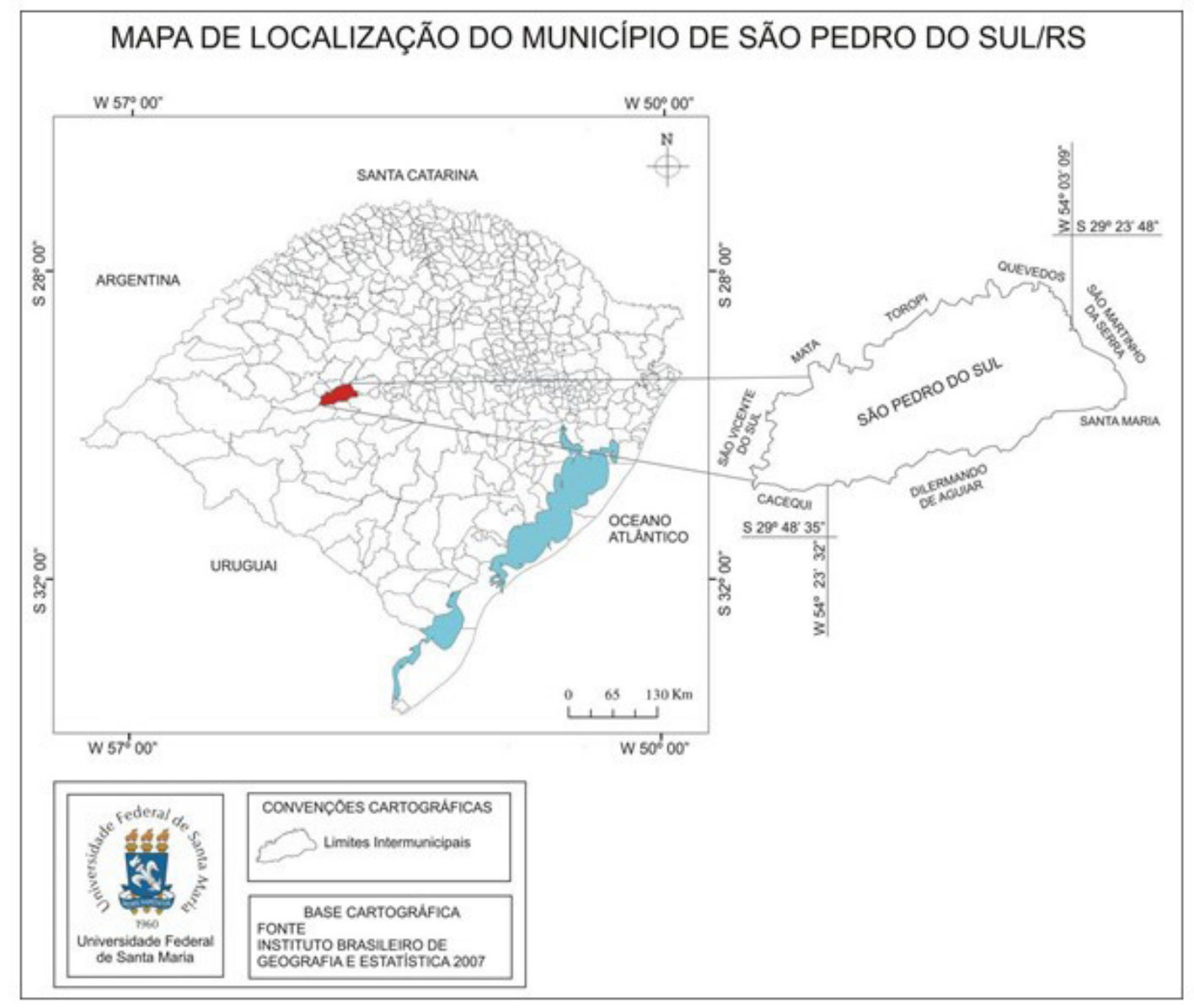

Figura 01- Mapa de localização do município de São Pedro do Sul/RS.

A escolha pela quinta série do Ensino Fundamental ocorreu em virtude de que segundo os Parâmetros Curriculares Nacionais (PCNs) é nesta etapa que os educandos têm um primeiro contato com o estudo da cartografia na Geografia.

Desta maneira, a presente pesquisa teve como objetivo geral elaborar um jogo digital capaz de auxiliar no processo de alfabetização cartográfica e validá-lo com os sujeitos do ensino e aprendizagem da Geografia. Especificamente, buscou-se: verificar a contribuição do jogo sob a perspectiva da aprendizagem significativa; analisar os limites e as possibilidades das TICs incorporadas na prática pedagógica de Geografia e contribuir com os sujeitos da educação por meio da inserção do jogo digital cartográfico.

\section{Materiais e Métodos}

Primeiramente, realizou-se um aprofundamento nas questões teórico-metodológicas por meio do resgate teórico, buscando na revisão bibliográfica, subsídios para o enriquecimento do trabalho. A pesquisa bibliográfica propiciou a operacionalização dos conceitos fundamentais da pesquisa: TICs na educação, alfabetização cartográfica e estudo do lugar.

Geografia Ensino \& Pesquisa, v. 16, n.2 p. 183 - 199, maio/ago. 2012

Dambros, G.; Rovani, F. F. M.; Quoos, J. H.; Cassol, R.. 
Os PCNs constituíram-se nos instrumentos para a seleção do conteúdo sobre alfabetização cartográfica e definição do público-alvo da pesquisa. Optou-se por seguir este documento, uma vez que, compõe uma gama de orientações curriculares em nível nacional.

Resgatadas e definidas as matrizes teóricas, na segunda etapa da pesquisa, iniciou-se 0 processo de elaboração e/ou construção do jogo digital cartográfico. Após a elaboração do jogo fez-se a validação do mesmo.

Nesta pesquisa, adotou-se uma metodologia para elaboração do jogo digital baseada em Amante; Morgado (2001). As autoras definem quatro grandes etapas de desenvolvimento, sendo elas: concepção, planificação, implementação e avaliação e as caracterizam da seguinte forma

\begin{abstract}
[...] primeira visa traçar as linhas mestras do projecto, definindo, a partir da ideia inicial, a aplicação que se pretende desenvolver. A segunda diz respeito a todo o trabalho de pesquisa e planificação prévia que conduzirá à elaboração do storyboard ou guião de autor, fundamental para a fase de implementação. Por seu turno, a terceira fase diz respeito ao desenvolvimento propriamente dito da aplicação, ou seja, consiste na fase de mediatização do guião. A quarta e última fase relaciona-se com a testagem do produto no sentido de verificar se funciona como previsto, se se adequa ao público alvo, se cumpre os objectivos visados, em suma, se o produto apresenta as características técnicas, funcionais, didácticas e de design que lhe exigimos (AMANTE; MORGADO 2001, p.127).
\end{abstract}

1 Para Preece; Rogers; Sharp (2002. p.263) "um storyboard consiste em uma série de desenhos mostrando como um usuário pode progredir em uma tarefa utilizando o produto que está sendo desenvolvido: pode-se tratar de uma série de telas esboçadas, o caso de um sistema de software baseado em interfaces gráficas com 0 usuário".

Geografia Ensino \& Pesquisa, v. 16, n.2 p. 183 - 199, maio/ago. 2012

Cartografia interativa: jogo digital para a alfabetização cartográfica em São Pedro do Sul/RS

\section{Concepção}

A etapa da concepção refere-se à fase inicial do desenvolvimento do jogo, na qual estabeleceu-se a temática principal, os pressupostos teóricos e analisou-se as possibilidades de sua realização.

O jogo digital teve como objetivo principal abordar conteúdos referentes a alfabetização cartográfica e trabalhar o processo de mapeamento de forma lúdica e interativa. 0 jogo seria, portanto, um recurso didático pedagógico no processo de ensino-aprendizagem da cartografia para o Ensino Fundamental.

Definiu-se que o jogo deveria proporcionar um conhecimento teórico do conteúdo, permitindo também que os alunos vivenciassem as funções do cartógrafo, no ato de mapear, essenciais para a leitura de mapas.

\section{Planificação}

A planificação diz respeito à pesquisa de conteúdo e a estruturação inicial do jogo que conduziram a elaboração do storyboard"1.

A pesquisa de conteúdo foi realizada por meio de levantamentos teóricos sobre 0 assunto em várias fontes (materiais impressos, livros, artigos, e textos disponibilizados na Internet), bem como nos PCNs que consistem em propostas curriculares em nível nacional.

Realizou-se um estudo e pesquisa do conteúdo cartográfico, aquisição/produção de mapas, seleção de imagens de satélite e captura de fotos da área urbana do município de São Pedro do Sul.

Determinou-se os principais critérios do design da interface, a navegação, as ferramentas, o formato dos textos, as instruções da atividade, entre outros elementos, visando a uma maior interatividade com o usuário. 


\section{Implementação}

Esta fase caracteriza-se pelo início efetivo do desenvolvimento do jogo. Analisou-se as ferramentas de programação a serem utilizadas e também a elaboração da primeira versão (protótipo) do jogo.

A interface visual do jogo foi desenvolvida nos seguintes softwares: Poser para desenvolvimento do agente pedagógico; Adobe llustrator CS4 para edições nas ilustrações e Adobe Photoshop CS4 utilizado no tratamento das imagens. Para a produção dos mapas utilizou-se 0 aplicativo ArcGis 9.3. A programação foi realizada no Adobe Flash CS4, Actionscript 3.0 (código de programação usado no Adobe Flash CS) e Flash Player 8.0 (para rodar a programação).

A escolha pelo Adobe Flash CS está relacionada ao número de possibilidades de aplicações interativas que o software permite.

\section{Avaliação}

Conforme Amante; Morgado (2001) a avaliação permite identificar os aspectos positivos e negativos alcançados na aplicação sendo que esta etapa completa o ciclo de desenvolvimento do recurso didático, mas não o encerra podendo reabri-lo.

A etapa de avaliação efetivou-se na validação da aplicação educativa. Consistiu em "testar" o funcionamento do jogo, sua adequação ao público-alvo e se o recurso atingiu aos objetivos junto aos sujeitos da pesquisa.

O jogo digital teve sua aplicabilidade executada na quinta série do Ensino Fundamental da Escola Estadual de Educação Básica Tito Ferrari, localizada no município de São Pedro do Sul/ RS. No primeiro momento, realizou-se um contato com a direção da Escola, a fim de apresentar os objetivos do trabalho e avaliar a possibilidade de realização da pesquisa.

Posteriormente, buscou-se contato e diálogo com a professora titular das turmas de quinta série no qual foram apresentados, respectivamente, a pesquisa e o jogo digital que seria trabalhado com os educandos. Nesse momento, fez-se uma apresentação minuciosa do recurso didático a docente da turma (de forma que esta pudesse compreender claramente quais os objetivos a serem ali alcançados), e também a sua opinião sobre o jogo. Na sequência, discutiu-se as possibilidades de trabalhar o jogo com os discentes e planejou-se a realização das atividades.

A validação do jogo digital ocorreu no mês de novembro de 2011, no decorrer de uma semana letiva. Utilizou-se uma aula em cada turma, sendo cada período de cinquenta minutos. Teve-se como público alvo duas turmas de quinta série: a turma 53 (composta por 27 alunos) e a turma 54 (composta por 25 alunos).

Para a aplicação do jogo, inicialmente, fez-se uma explicação básica sobre os objetivos da pesquisa e funcionamento do recurso e em seguida os alunos foram alocados no laboratório de informática da Escola e orientados a iniciar a interação com o jogo. Após a validação do jogo aplicou-se um questionário, como instrumento de pesquisa, contendo questões relativas ao uso do jogo e participação dos alunos no trabalho.

\section{Resultados e Discussão}

Geografia Ensino \& Pesquisa, v. 16, n.2 p. 183 - 199, maio/ago. 2012

\section{Pedrinho em: conhecendo o mapa}

O foco central da pesquisa materializou-se em "Pedrinho em: conhecendo o mapa", um jogo digital que trabalha as noções básicas da alfabetização cartográfica de forma lúdica e interativa.

Dambros, G.; Rovani, F. F. M.; Quoos, J. H.; Cassol, R.. 
Desse modo, pretendeu-se desenvolver nos educandos as habilidades de mapeadores, como 0 (re)conhecimento da visão vertical e dos elementos cartográficos presentes em um mapa: escala, orientação, titulo, coordenadas e legenda.

No jogo primeiramente tem-se a tela inicial (Figura 02), que apresenta os autores, a identidade visual e o nome do mesmo, como forma de se representar o conteúdo proposto. A tela destaca a Praça Crescêncio Pereira em São Pedro do Sul/RS e o agente pedagógico Pedrinho. Enfatiza-se que a tela inicial deve ser atrativa para motivar 0 aluno a iniciar a interação.

A próxima tela (Figura 03) representa o início efetivo da interação com o jogo, pois ao mesmo tempo em que faz o convite, propõe um desafio, ou seja, explorar o universo dos mapas a partir da área urbana do Município.

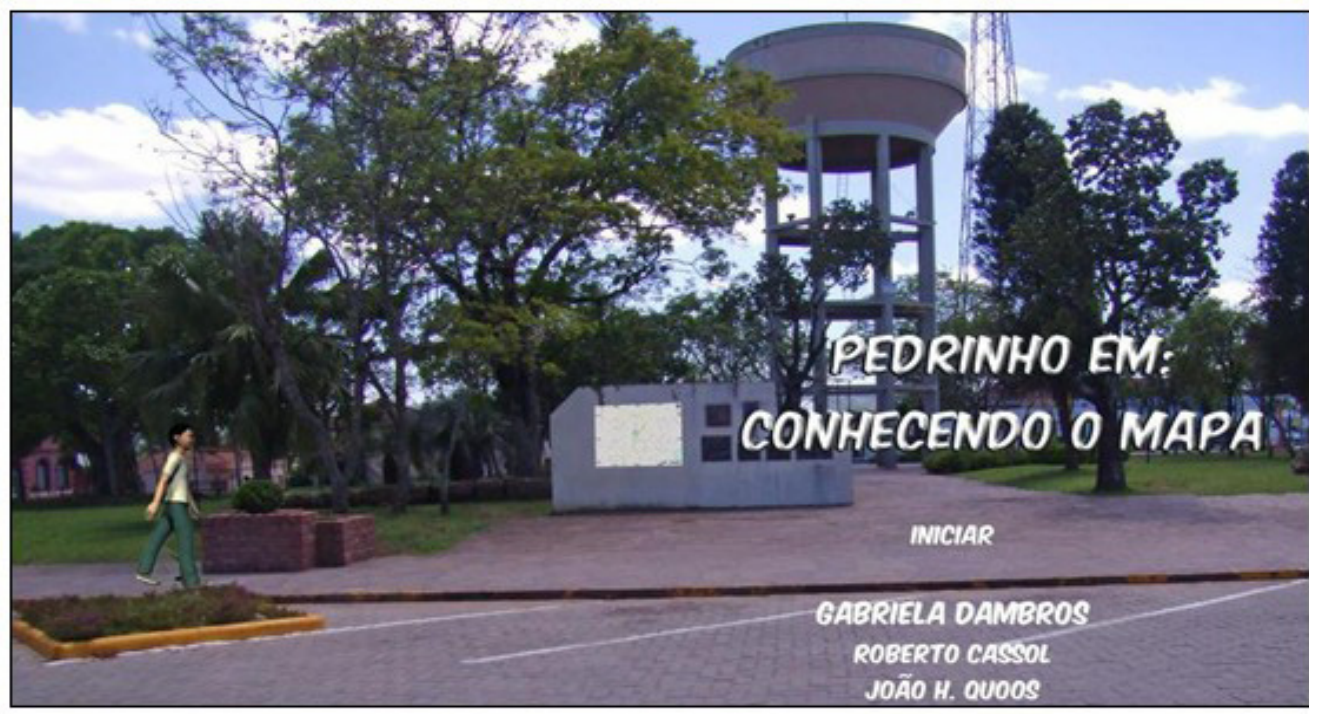

Figura 02- Tela inicial do jogo.

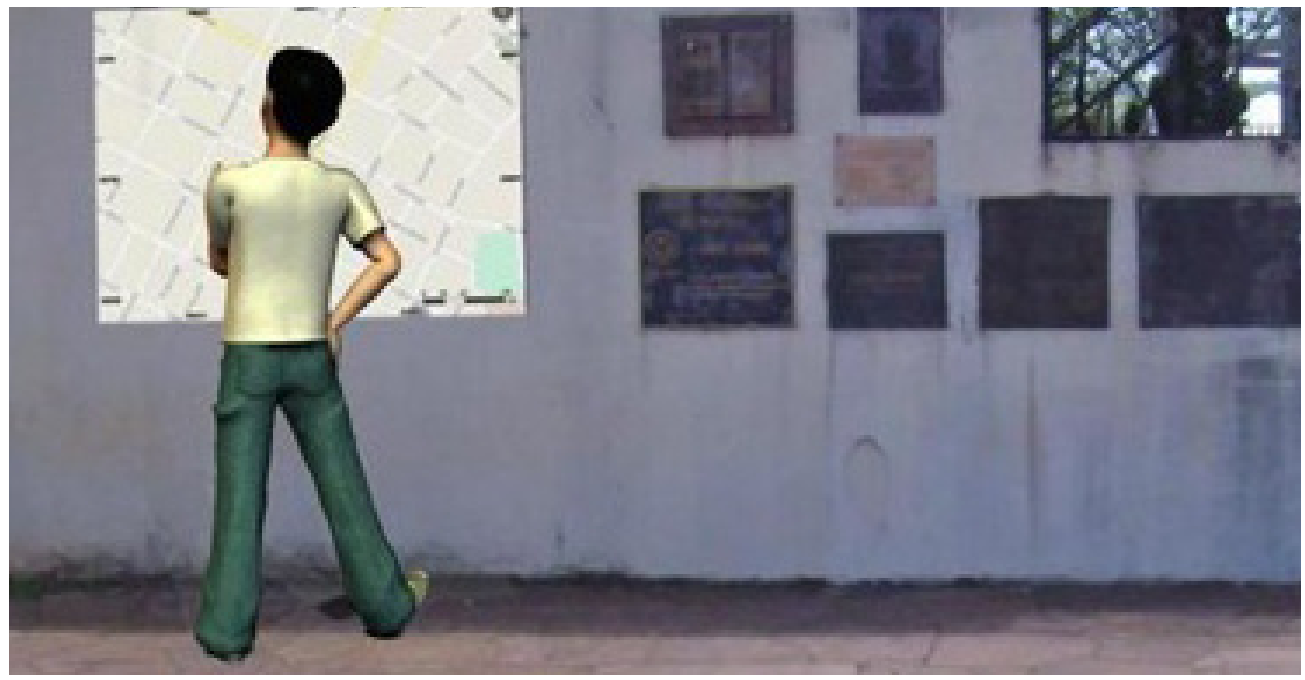

Geografia Ensino \& Pesquisa, v. 16, n.2 p. 183 - 199, maio/ago. 2012

Cartografia interativa: jogo digital para a alfabetização cartográfica em São Pedro do Sul/RS

188

ISSN 2236-4994
Figura 03- Tela convite à interação com o jogo.

A proposta da tela 03 centra-se na especificação do tipo de desafio proposto ao educando: ser um mapeador e, consequentemente, um leitor de mapas. Pode-se observar que, a partir desta tela 0 aluno interage com o jogo, podendo prosseguir para as etapas posteriores.

As telas possuem a opção de mobilidade representada pela seta de avançar, processo esse necessário para a introdução à navegação do jogo, quando o educando aceitar o desafio proposto que é o de buscar elementos para aprender a elaborar um mapa. 
No jogo, a interação com o agente pedagógico é realizada de modo textual, por meio de balões com mensagens de texto e gestual, que ocorre com as mudanças de estado físico do agente.

A primeira "missão" dada ao Pedrinho é a de orientar-se até a Biblioteca Municipal a fim de buscar uma trena que será utilizada para medir a quadra em frente à praça (Figura 04).

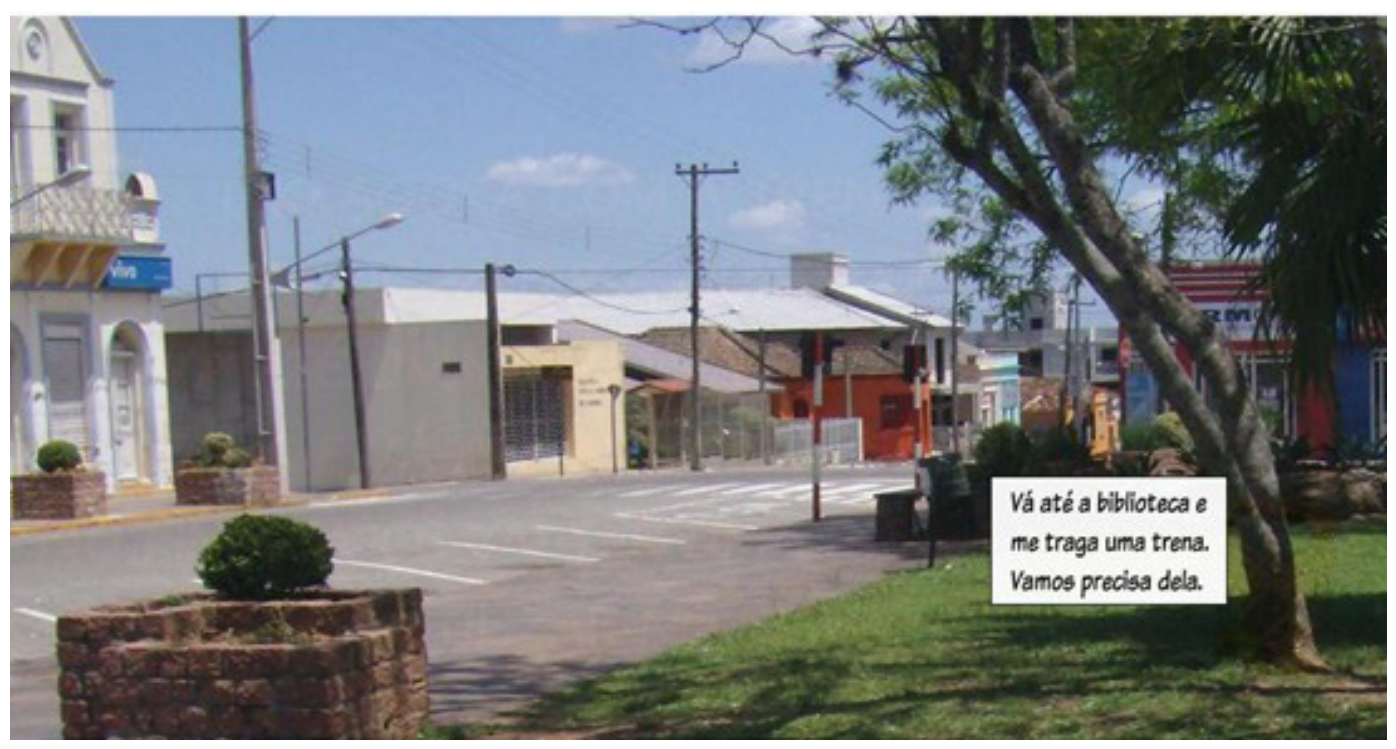

Figura 04- Tela do primeiro desafio do jogo.

Ao chegar à Biblioteca, Pedrinho irá visualizar a trena que encontra-se em meio aos livros. Nesse momento, o jogador irá clicar sobre a trena, sendo que, após esta ação, o jogo encaminhará para a tela onde orienta-se a medição da distância entre as duas esquinas (Figura 05). Ao medir a quadra obtêm-se 92 metros (Figura 06). Esta distância será utilizada posteriormente na elaboração da escala do mapa.

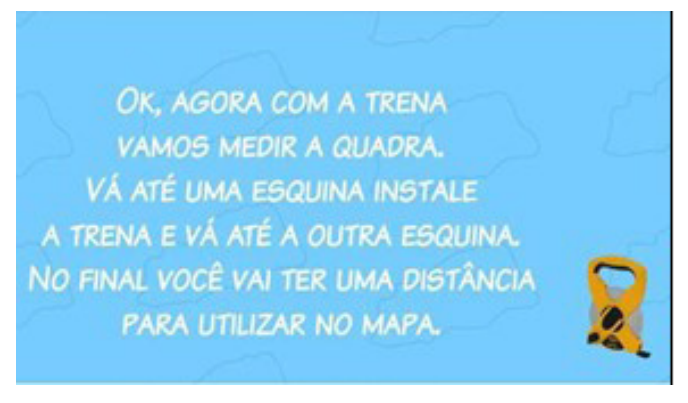

Figura 05- Atividade de medir a quadra.

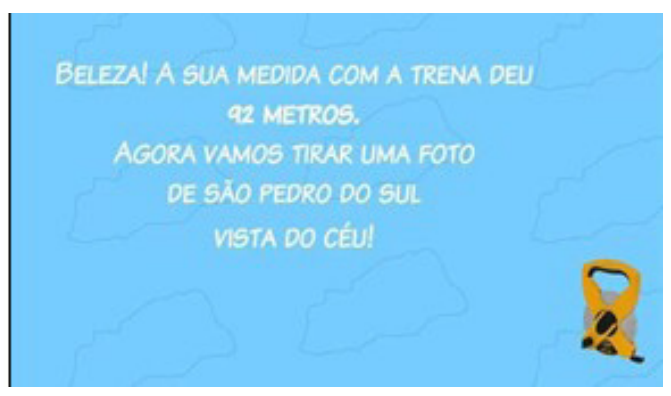

Figura 06- Tela com resultado da medida.

Como sequência, o mapa convida Pedrinho a soltar um balão e ter uma "visão de cima" da cidade, porque os mapas são elaborados a partir de fotografias aéreas ou imagens de satélite que retratam o espaço segundo a visão vertical (Figura 07). Procurou-se demonstrar a representatividade do espaço a partir da visão vertical. 


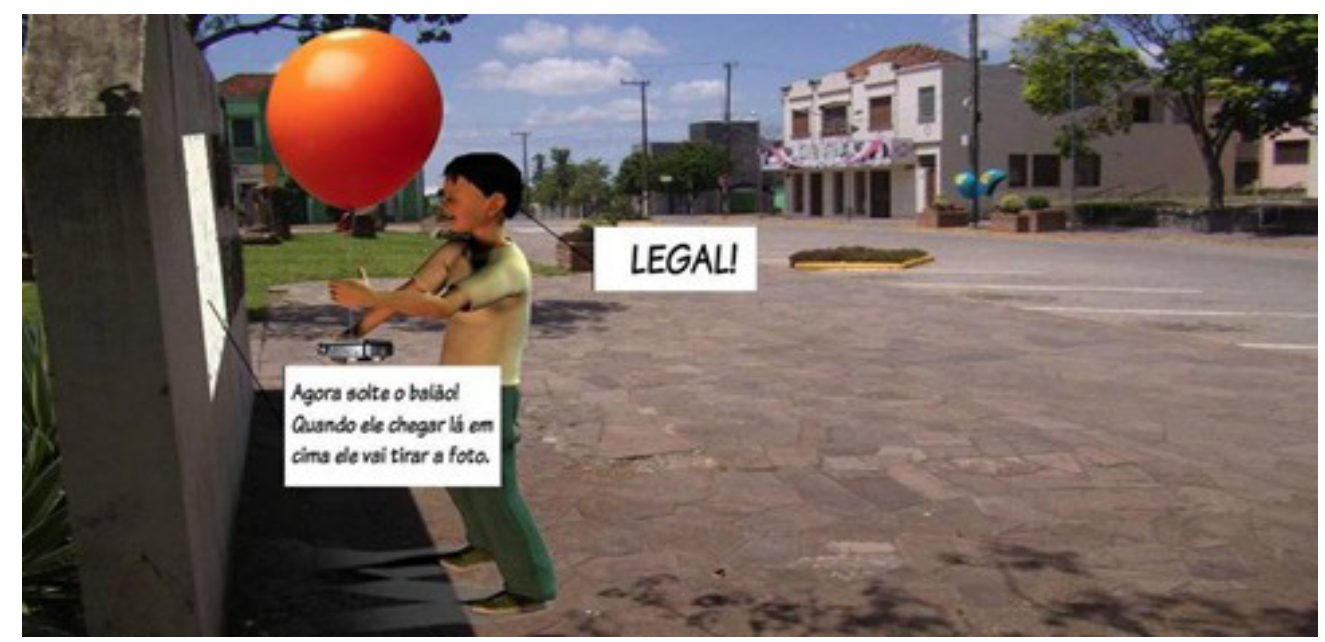

Figura 07- Tela da visão vertical.

$\mathrm{Na}$ etapa seguinte alerta-se que para a construção do mapa precisa-se de mais um instrumento (bússola) que servirá para orientar o mapa que será produzido. Para isto, é lançado o desafio: Pedrinho deve orientar-se até o Museu Histórico Municipal Fernando Ferrari que localizase juntamente com o Museu Paleontológico e Arqueológico Walter llha (Figura 08).

Ao chegar ao Museu, Pedrinho encontra uma bússola e recebe a instrução para retornar ao ponto inicial, ou seja, ao mapa encontrado na Praça e a partir de então iniciar a elaboração de um mapa (Figura 09).

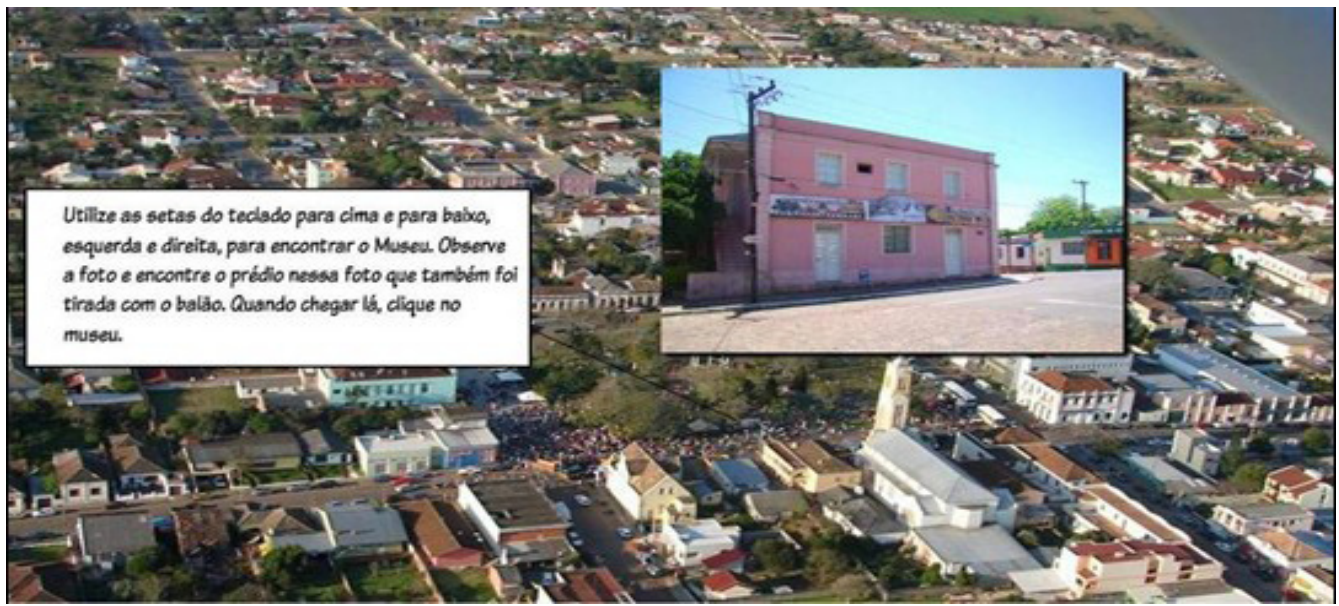

Figura 08- Tela desafio de buscar a bússola no Museu.

Geografia Ensino \& Pesquisa, v. 16, n.2 p. 183 - 199, maio/ago. 2012

Cartografia interativa: jogo digital para a alfabetização cartográfica em São Pedro do Sul/RS

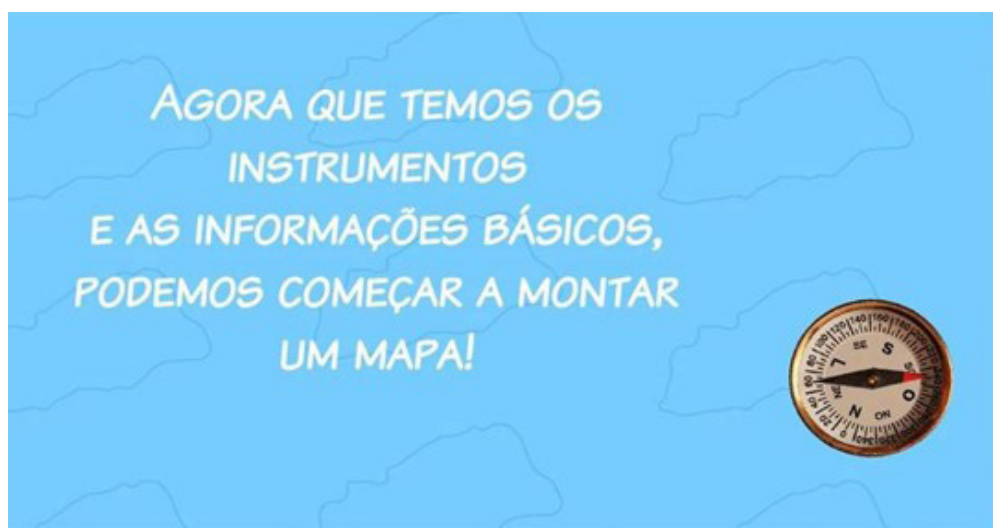

Figura 09- Tela com a bússola encontrada. 
A tela seguinte expõe uma breve explicação sobre a fotografia feita com o balão e sobre a visão vertical (Figura 10). Nesse momento, o jogo explicita a importância de uma vista "de cima" da área para a elaboração do mapa. 0 propósito é que o educando compreenda as diferenças entre visão vertical, horizontal e oblíqua podendo visualizar o Museu nas três visões diferentes utilizando apenas as setas do teclado do computador.

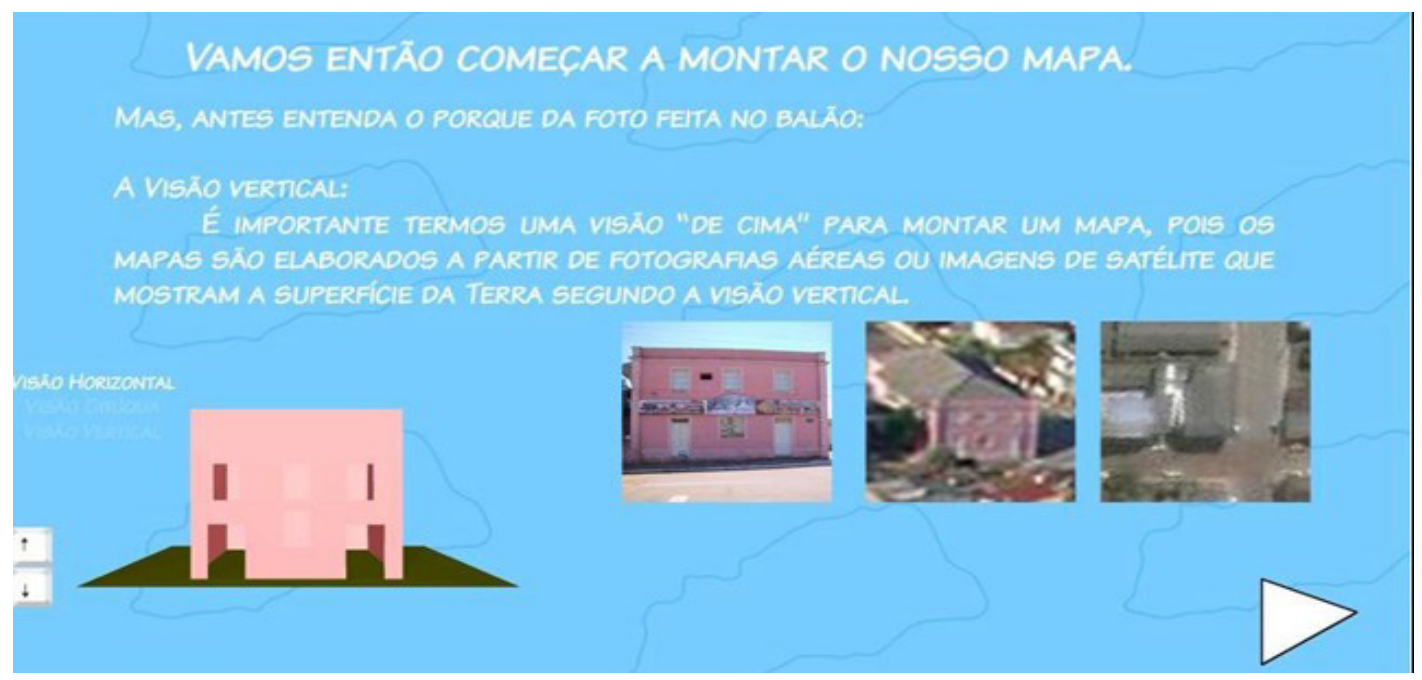

Figura 10- Início da elaboração do mapa.

Para dar início ao processo de elaboração do mapa, o educando deve localizar Pedrinho a partir da visão vertical (Figura 11). Ao superar as etapas anteriores entende-se que 0 aluno já consegue "se ver de cima" localizando o personagem na imagem. Para tanto, ele pode utilizar-se de pontos de referência que facilitem este processo.

Após localizar-se, o mapa irá pedir que o jogador comece a traçar as ruas, também a partir da imagem aérea. 0 aluno irá "desenhar" duas ruas da área urbana e o mapa terminará de traçar as demais ruas propondo que na sequência utilize-se a bússola encontrada para orientar o mapa (Figura 12).

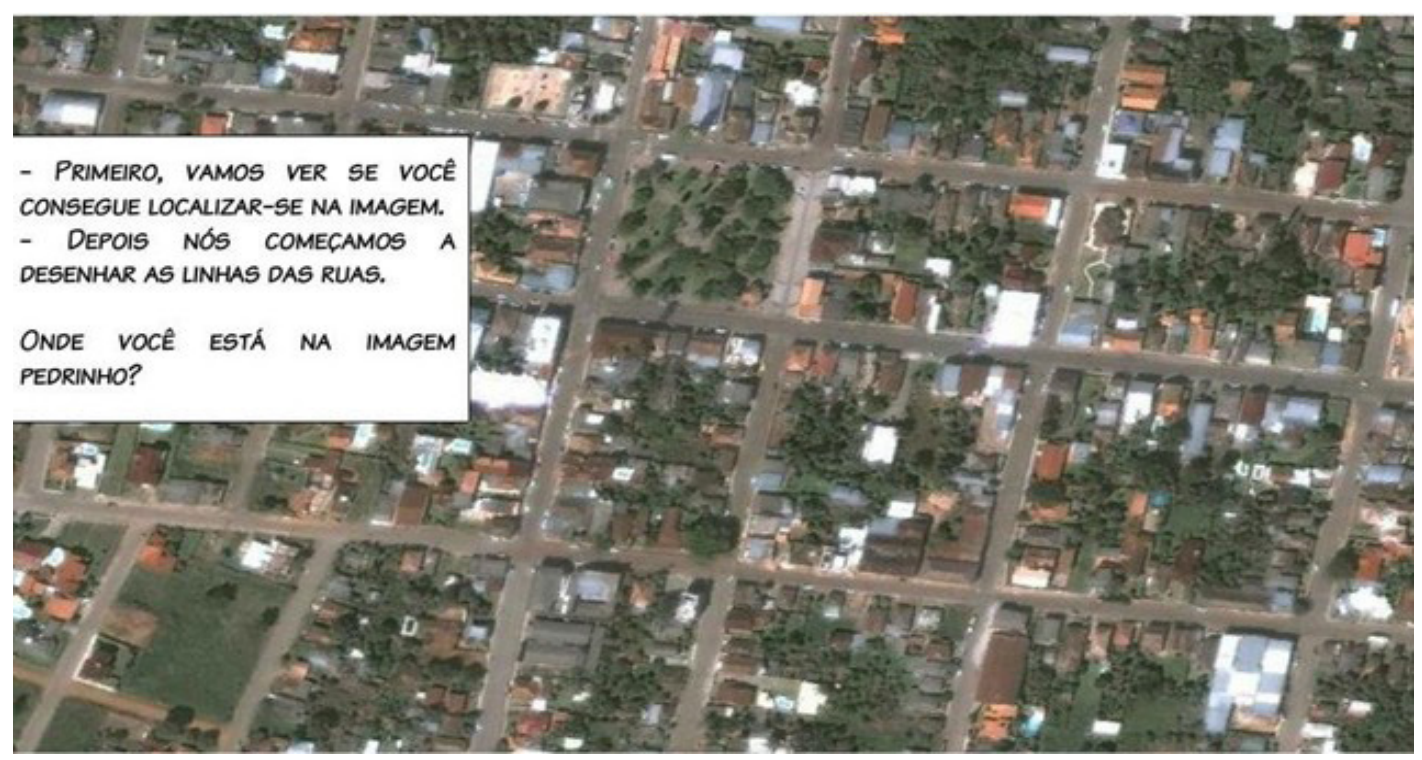

Figura 11- Localização do Pedrinho.
Geografia Ensino \& Pesquisa, v. 16, n.2 p. 183 - 199, maio/ago. 2012

Dambros, G.; Rovani, F. F. M.; Quoos, J. H.; Cassol, R.. 


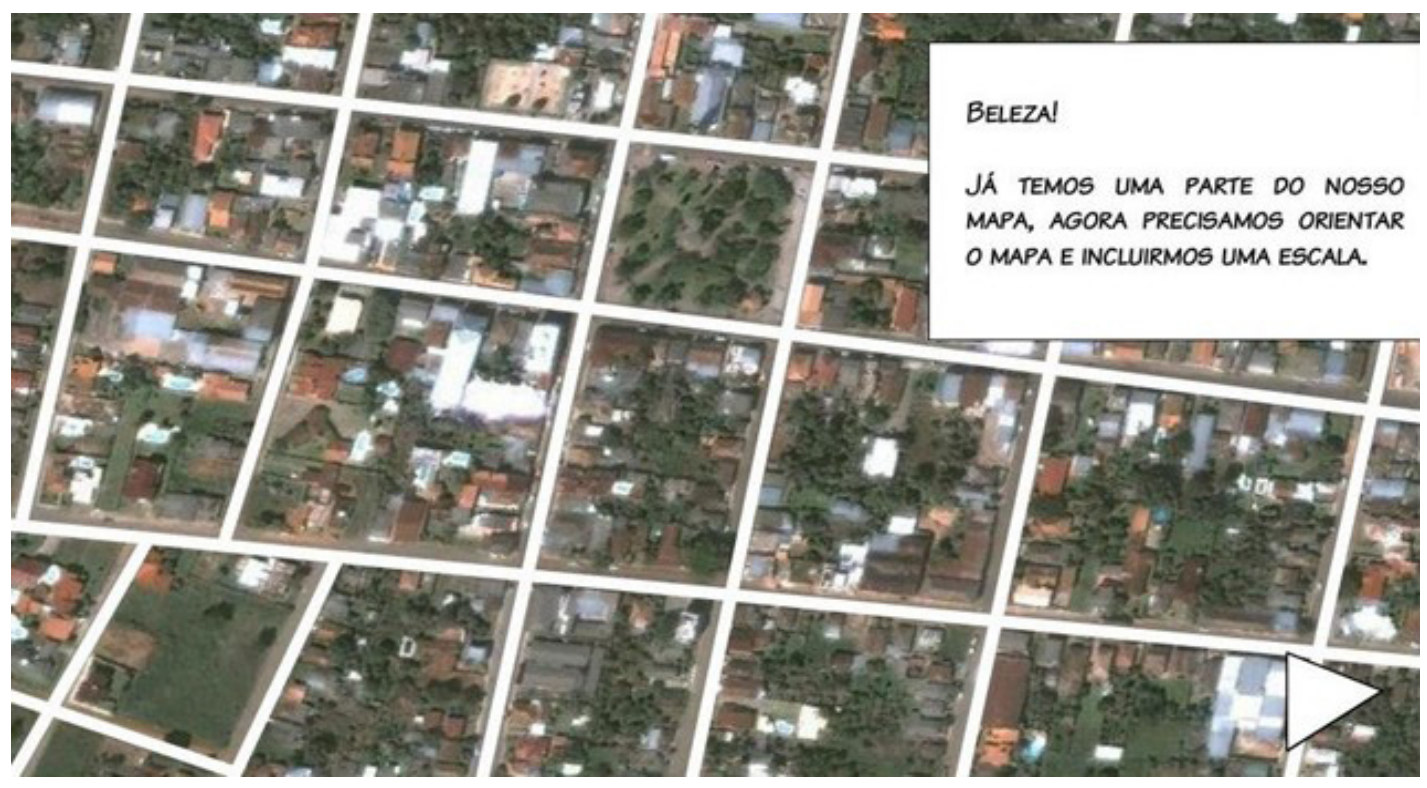

Figura 12- Ruas desenhadas.

A tela seguinte expõe uma breve explicação sobre orientação (Figura 13), a origem dos pontos cardeais e o movimento aparente do sol destacando a importância destes elementos para a construção do mapa e sugere a utilização da bússola, encontrada no Museu anteriormente.

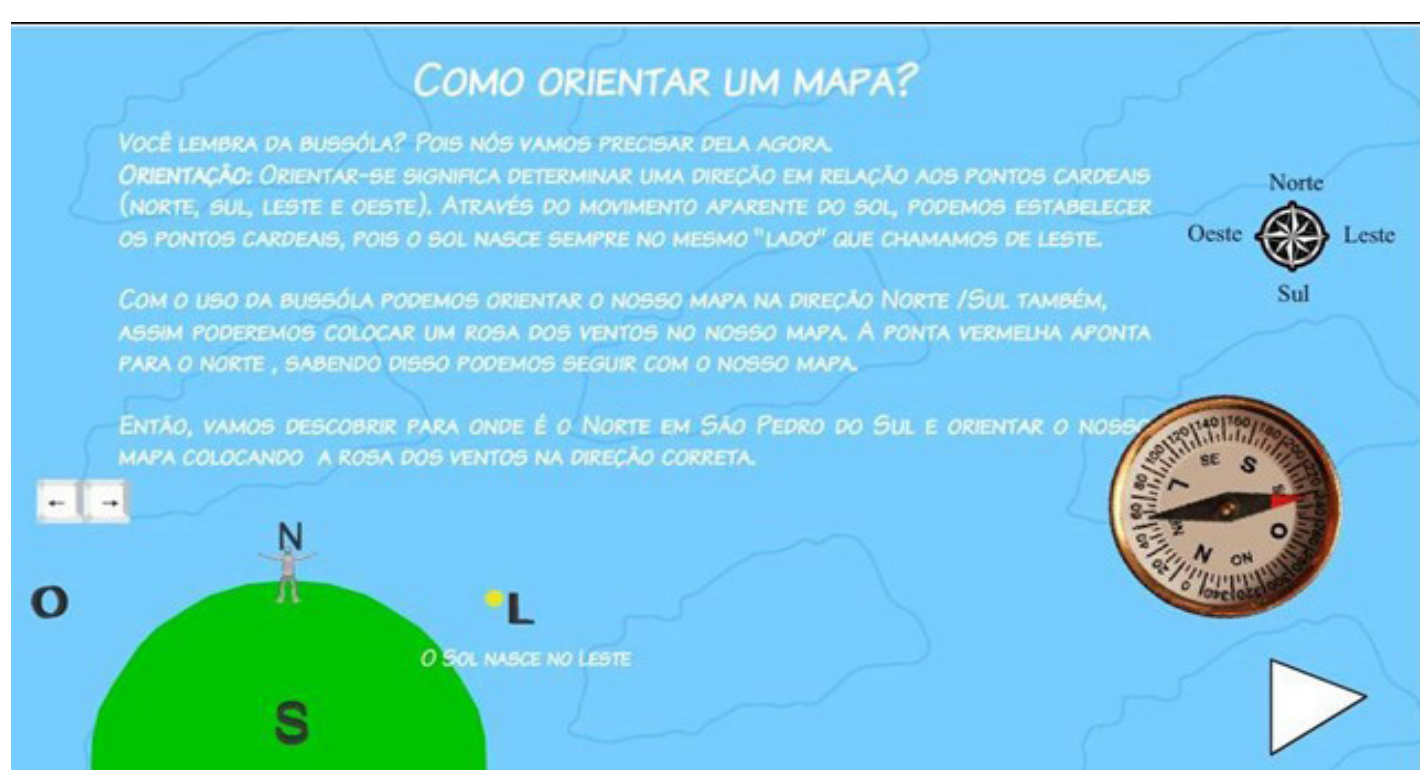

Figura 13- Tela de explicação sobre orientação.

Geografia Ensino \& Pesquisa, v. 16, n.2 p. 183 - 199, maio/ago. 2012

Cartografia interativa: jogo digital para a alfabetização cartográfica em São Pedro do Sul/RS
Na tela 14 apresenta-se a bússola e como orientá-la. O jogador deve ir clicando até orientar a bússola corretamente, colocando o norte da agulha em consonância com o norte da bússola. 


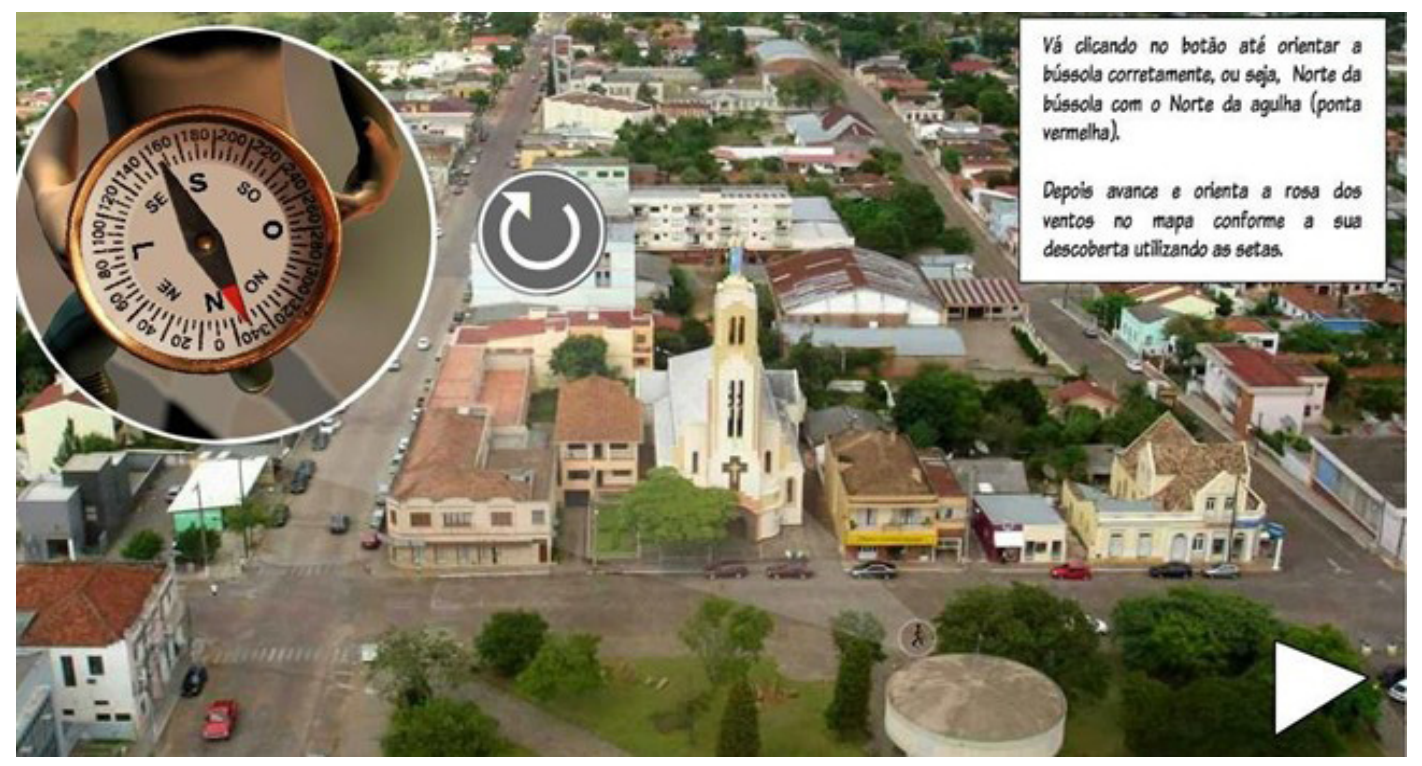

Figura 14- Atividade de orientar o mapa.

Com a bússola já orientada o elemento cartográfico orientação é inserido no mapa (Figura 15). Nesse momento o jogador deverá orientar a rosa dos ventos corretamente, de acordo com a imagem vertical da cidade, apontando o "N" para o norte.

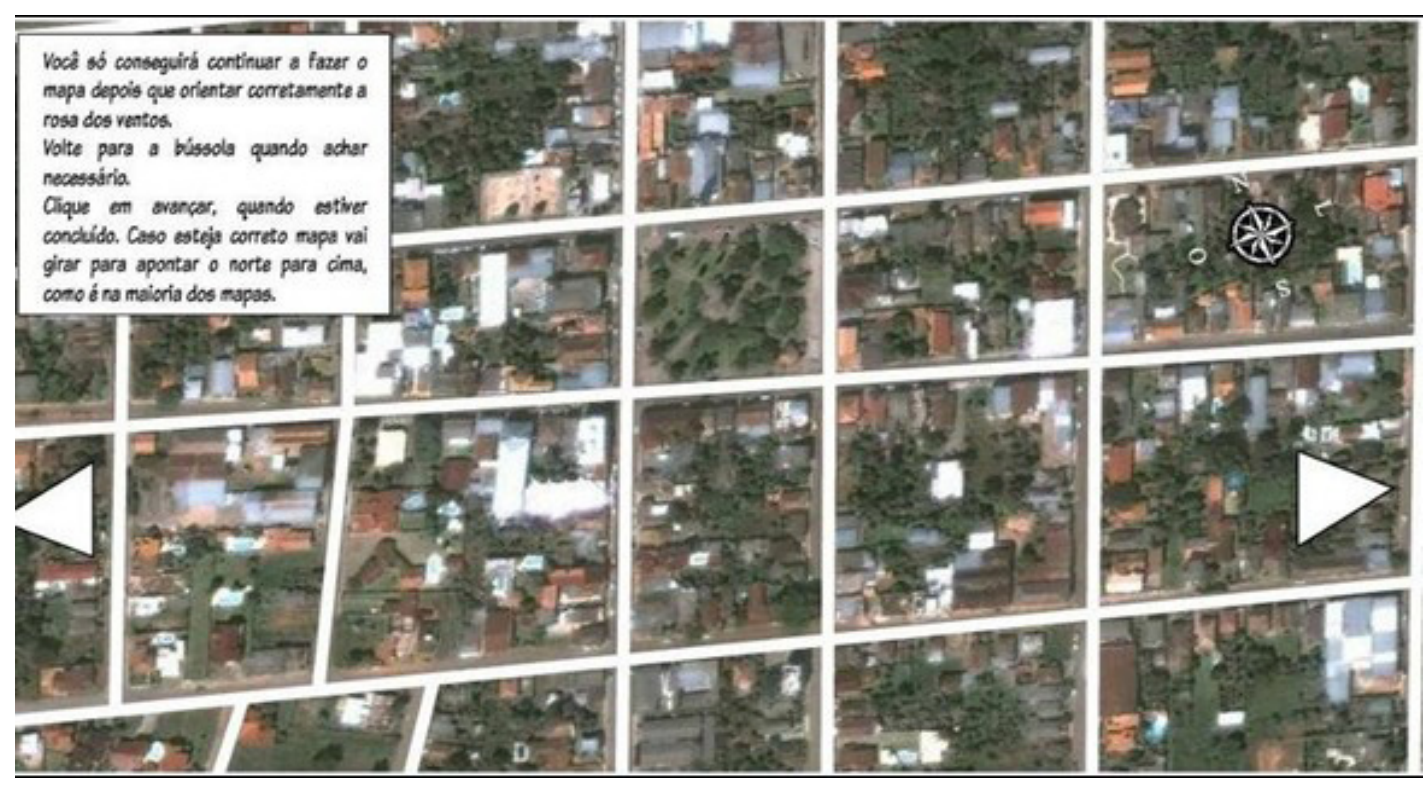

Figura 15- Tela do mapa já orientado.

Na tela 16, retoma-se, a medida realizada no início do jogo, a qual apontava a distância, em metros, entre as duas esquinas. Dessa forma, explica-se a função desta medida na construção da escala do mapa.

Geografia Ensino \& Pesquisa, v. 16, n.2 p. 183 - 199, maio/ago. 2012

Dambros, G.; Rovani, F. F. M.; Quoos, J. H.; Cassol, R.. 


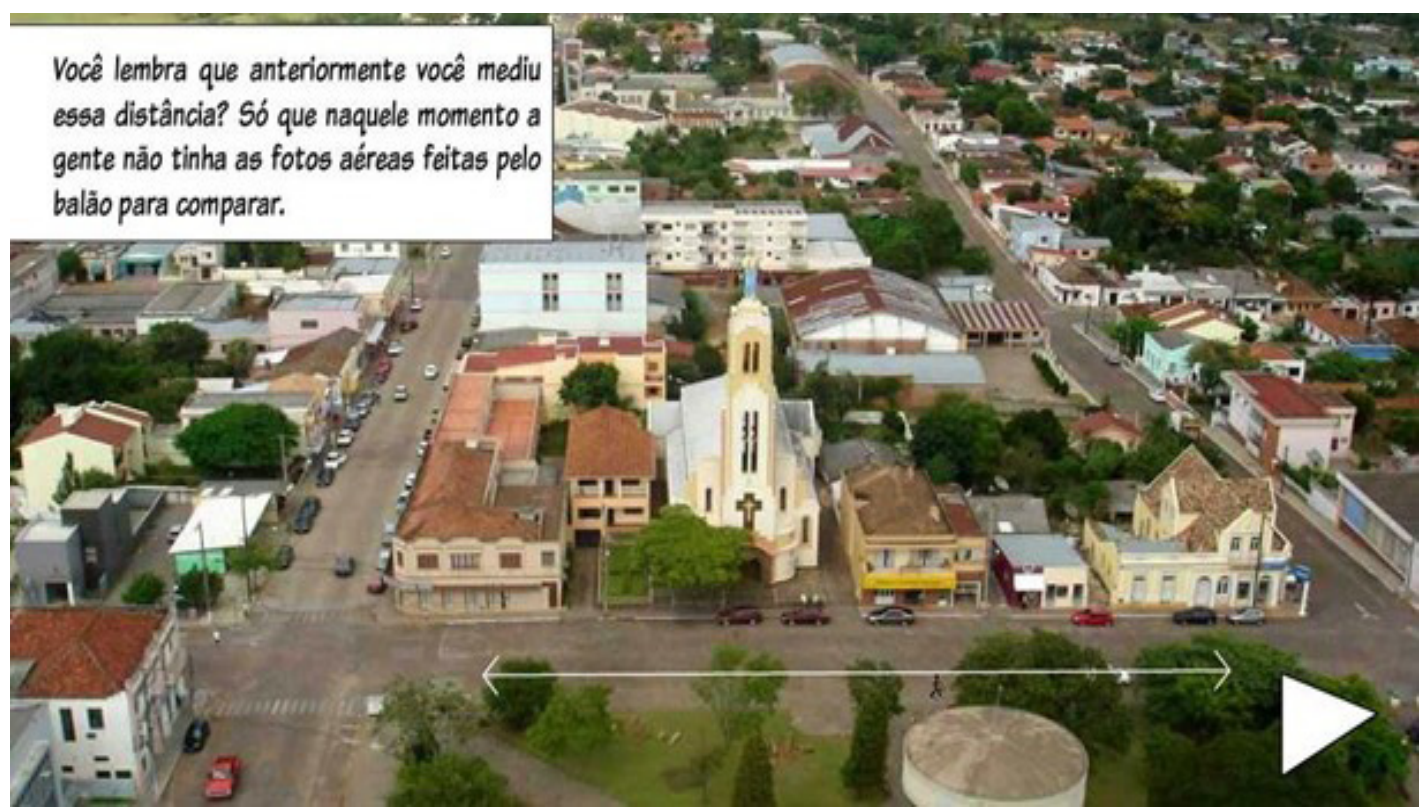

Figura 16- Explicação sobre construção da escala.

Na subsequência tem-se o mapa com uma escala gráfica definida, que mostra a distância entre as duas esquinas. Com essa escala, o educando poderá realizar outras medidas dentro do mapa construído por ele (Figura 17).

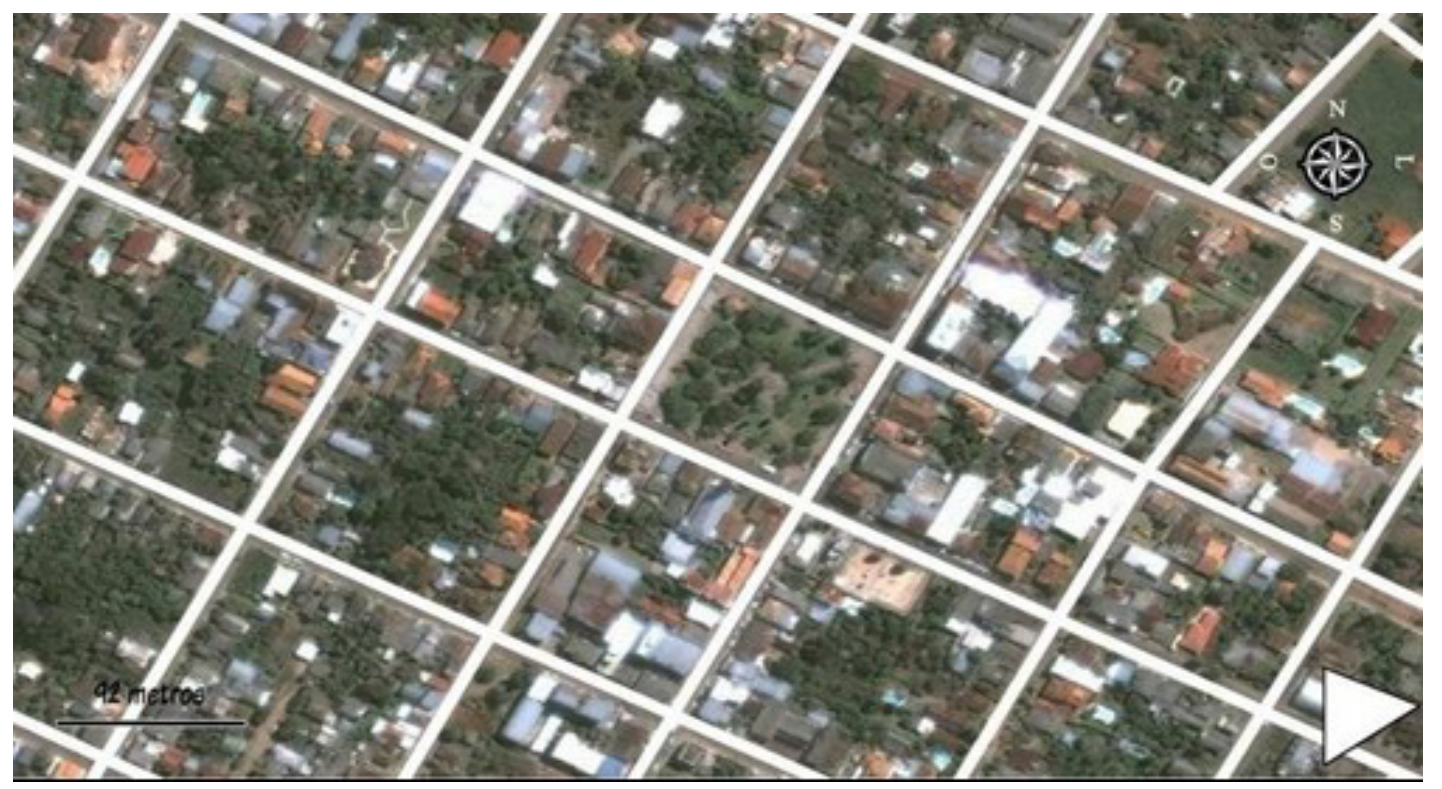

Figura 17- Mapa com a escala construída.

$\mathrm{Na}$ tela 18 apresenta-se o elemento cartográfico legenda, com um texto explicativo, ao

Geografia Ensino \& Pesquisa, v. 16, n.2 p. 183 - 199, maio/ago. 2012

Cartografia interativa: jogo digital para a alfabetização cartográfica em São Pedro do Sul/RS 


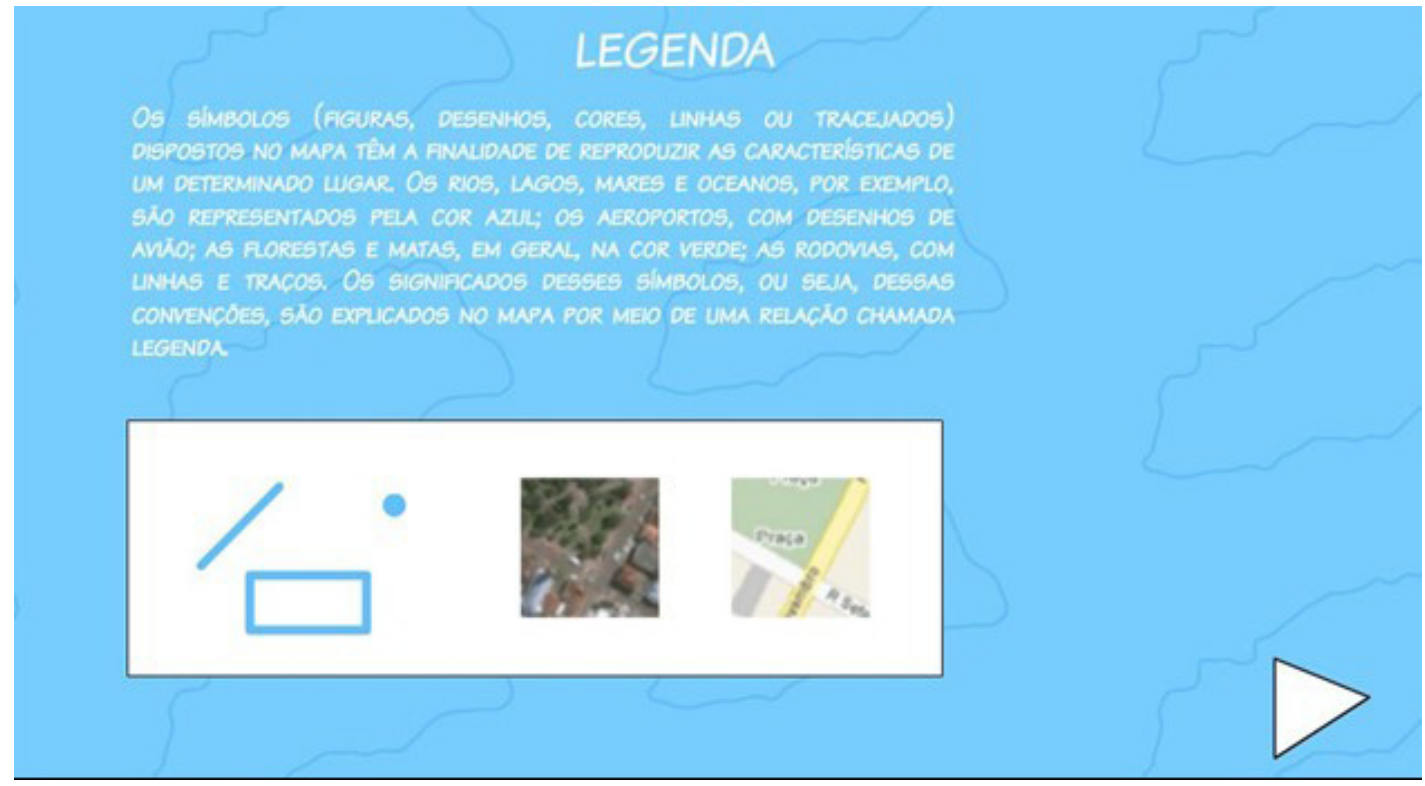

Figura 18- Elemento cartográfico legenda.

Por fim, ao superar os desafios propostos, tem-se um mapa interativo, no qual o educando poderá utilizar seus conhecimentos de mapeador (Figura 19). Nesse mapa, o aluno tem disponível uma série de ferramentas que possibilitam o mapeamento e a realização de algumas edições no mapa (Figura 20).

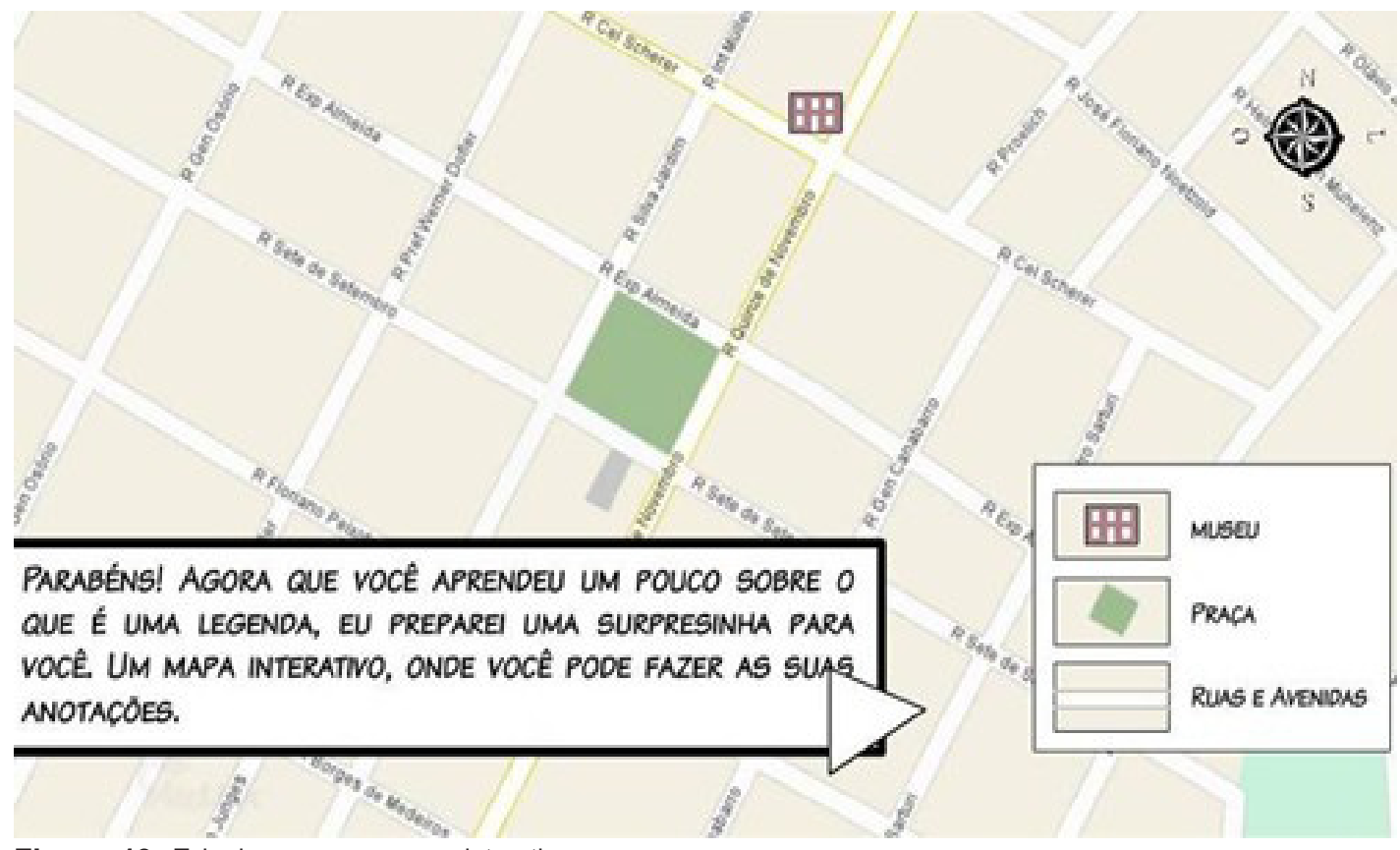

Figura 19- Tela de acesso ao mapa interativo. 


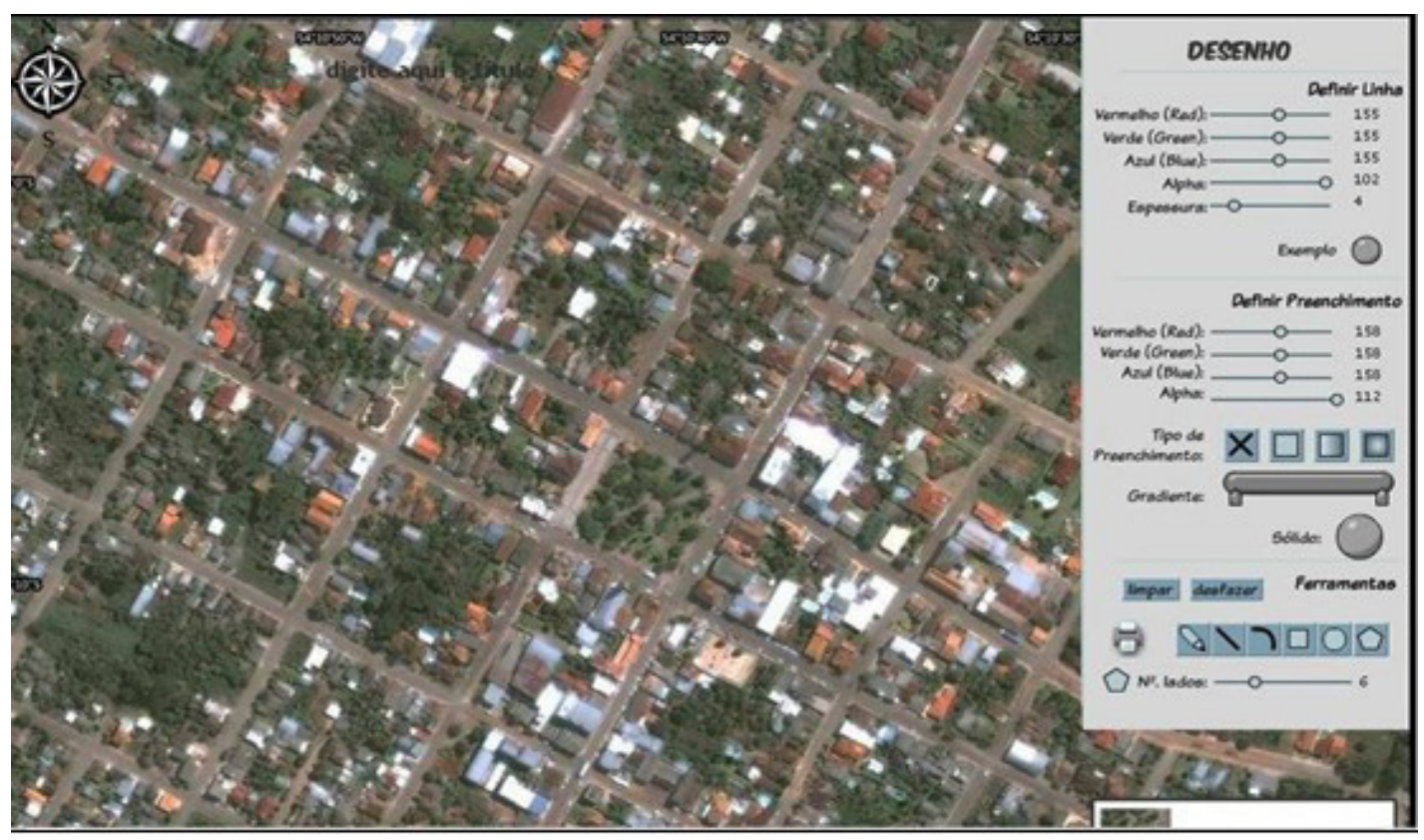

Figura 20- Mapa interativo.

Ressalta-se que, o jogo produto final deste trabalho, está disponivel na Internet no link http:// www.ufsm.br/geografia/pedrinho. A publicação do jogo na Internet permitirá que outras escolas do Município (e demais interessados) tenham acesso ao recurso de forma simples e gratuita.

\section{A validação do jogo: relatos da experiência}

A validação desta pesquisa ocorreu por meio da avaliação da aplicabilidade prática do jogo digital juntamente com os alunos da quinta série (turmas 53 e 54) da Escola Estadual de Educação Básica Tito Ferrari.

Além da análise empírica da pesquisadora e da professora regente, durante esse processo, buscou-se obter um parecer específico dos alunos/jogadores tanto para as características técnicas, quando as pedagógicas.

Os educandos da turma 53 encontraram dificuldades na interação com o jogo, sendo que alguns não alcançaram a última fase, ou seja, a etapa do "aluno mapeador". A maior dificuldade relatada por eles centrou-se na orientação e na visão vertical, pois eles estão acostumados com a visão horizontal e "enxergar a cidade de cima" apresentou-se como elemento novo.

Os educandos da turma 54 não encontraram maiores dificuldades na interação com o jogo, todos conseguiram chegar à última etapa proposta pelo recurso. Tal fato pode ser explicado por um maior conhecimento da temática em estudo.

Como etapa complementar propôs-se um questionário para avaliar a opinião dos alunos em relação à proposta desta pesquisa. Ao serem questionados se já haviam entrado em contato

Geografia Ensino \& Pesquisa, v. 16, n.2 p. 183 - 199, maio/ago. 2012

Cartografia interativa: jogo digital para a alfabetização cartográfica em São Pedro do Sul/RS

196

ISSN 2236-4994 com algum recurso didático semelhante antes da atividade desenvolvida em sala de aula todos responderam que não. Isso, já demonstra a importância da validação do jogo, uma vez que, este contribuiu de forma significativa por ser a primeira ferramenta pedagógica digital utilizada nas aulas de Geografia.

A segunda questão do questionário indagava como foi participar da pesquisa, procurou-se analisar a reação dos educandos com a inserção de uma "novidade" no processo de ensino e aprendizagem. Assim obtiveram-se as seguintes respostas: 
"Foi muito legal".

"Foi muito divertido".

"Muito legal interessante".

"Bom, bem legal".

"Muito bom uma coisa diferente".

No que se refere à avaliação dos alunos sobre o jogo digital (questão 3), destacam-se as seguintes opiniões:

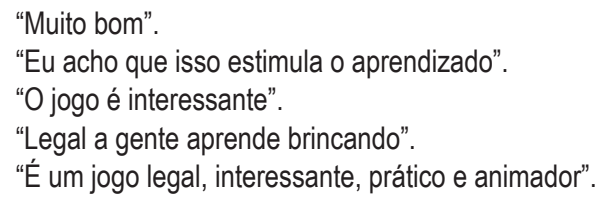

Quando questionados se a atividade desenvolvida os ajudou a entender melhor os elementos presentes em um mapa, novamente todas as respostas foram "sim" o que demonstra eficiência do jogo enquanto recurso didático pedagógico para a aprendizagem da alfabetização cartográfica.

No sentido de avaliar a importância do lugar como ponto de partida para a alfabetização cartográfica e para uma aprendizagem significativa questionou-se se o fato de o jogo usar como "cenário" a cidade de São Pedro do Sul facilitou a realização das atividades. Nesse sentido, pode-se observar algumas respostas abaixo:

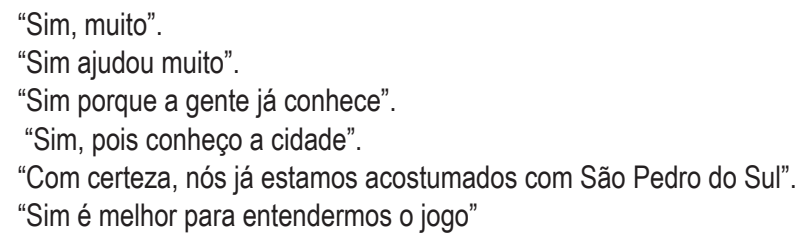

Tal fato só reforça a ideia de que o espaço vivido constitui-se em um elemento fundamental no processo de alfabetização cartográfica e que a leitura do mundo pode ser feita a partir do lugar e com o uso de mapas. De forma geral destaca-se que os alunos se sentiram motivados em realizar uma atividade diferente do cotidiano e também em responder aos desafios propostos pelo jogo que se trabalhados de forma tradicional tornar-se-iam exaustivos e de difícil apreensão.

Com o uso jogo digital em sala de aula as relações entre prática e teoria tornaram-se possíveis, visto que, os educandos puderam aprender sobre o processo de elaboração de um mapa assim como os elementos cartográficos que constituem um mapa e também desempenharam a função de mapeadores do espaço de vivência deles.

\section{Conclusões}

As tecnologias aplicadas à educação vêm auxiliando cada vez mais, alunos e professores a compor uma relação não mais restrita ao quadro - conteúdo - professor como detentor do saber, mas sim em educando e educador compartilhando e trocando saberes e experiências de aprendizagem. 0 educando não se restringe somente ao que o professor explicita em aula, mas com o uso das TICs, ele tem a chance de expandir seus horizontes e compartilhar conhecimentos com os demais.

"Pedrinho em: conhecendo o mapa" procurou atrelar o espaço vivido dos educandos aos conteúdos cartográficos e geográficos buscando a inserção dos sujeitos da educação nas práticas mediadas por TICs. Verificou-se que o fato de o jogo utilizar o espaço de vivência dos alunos facilitou a apreensão dos conteúdos e tornou a aprendizagem significativa.

Geografia Ensino \& Pesquisa, v. 16, n.2 p. 183 - 199, maiolago. 2012

Dambros, G.; Rovani, F. F. M.; Quoos, J. H.; Cassol, R..

ISSN 2236-4994 197 
Forneceu-se também subsídios para uma prática pedagógica que possibilita ao educando (re) conhecer o espaço local. Pode-se inferir que a apreensão da realidade do espaço vivido depende da percepção de cada indivíduo, ou seja, da visão de mundo que cada um desenvolve. Como afirma Boof (1997. p.9) "cada um lê com os olhos que tem. E interpreta a partir de onde os pés pisam [...]. A cabeça pensa a partir de onde os pés pisam. Para compreender, é essencial conhecer o lugar social de quem olha".

Constatou-se que para (re)significar os conteúdos geográficos é imprescindível que se associem as novas informações ao conhecimento empírico, valorizando aquilo que o educando já sabe, as experiências cotidianas, o espaço de vivência, para que os alunos possam atribuir significados ao conhecimento que está sendo construído.

Aponta-se que a escola, enquanto espaço de construção de conhecimento, saberes e valores, necessita incluir novas estratégias de ensino e aprendizagem que possam dar conta do atual estágio de desenvolvimento tecnológico vivenciado pela sociedade. Cabe ao professor promover a interação do aluno com a tecnologia, mediando a construção do conhecimento e proporcionando a transformação da prática pedagógica, através de um processo dialético de educação permanente.

Entendendo-se a realidade como algo em constante movimento, percebe-se que a (re)produção do espaço nunca estará pronta e acabada. Por isso, as TICs emergem como potenciais ferramentas a serem incorporadas na prática pedagógica de Geografia, a fim de articular conhecimentos de forma lúdica e interativa, contribuindo para uma aprendizagem significativa.

Todavia, ressalta-se que se faz imperativo uma reflexão do docente no que se refere à importância da aprendizagem mediada por TICs, uma vez que a tecnologia constitui-se em um recurso didático que deve contribuir no processo de ensino e aprendizagem , mas sozinha não garante necessariamente uma boa aula, tampouco substitui o papel do educador.

A validação da pesquisa aproximou os alunos e a professora das TICs no ensino de Geografia materializadas via jogo digital e a publicação do jogo na Internet que permitirá que outras escolas do Município tenham acesso ao recurso de forma simples e gratuita.

Pode-se afirmar que os jogos no ensino de Geografia têm potencial para contribuir no desenvolvimento de propostas mais holísticas na escola. A complexidade intrínseca ao espaço geográfico possibilita a elaboração de muitas propostas de produção de jogos e outros recursos didáticos, nas diversas linhas temáticas inerentes a Ciência Geográfica.

As TICs constituem-se em recursos auxiliares na construção do conhecimento, pois são agentes dinamizadores da prática pedagógica e tornam o ensino mais interessante, inclusivo e qualificado.

Acredita-se, portanto, que as TICs na escola despertam o interesse, promovem a inclusão digital, possibilitam uma autonomia do pensar e fazer, favorecem a leitura do mundo, propiciam a participação do educando na construção de uma sociedade mais justa e tornam a escola um ambiente democrático, dinâmico e com recursos para formar cidadãos que reconheçam seu papel enquanto atores que colaboram para (re)configurações socioespaciais.

Geografia Ensino \& Pesquisa, v. 16, n.2 p. 183 - 199, maio/ago. 2012

Cartografia interativa: jogo digital para a alfabetização cartográfica em São Pedro do Sul/RS

198

ISSN 2236-4994

\section{Referências}

ALMEIDA, Rosângela Doin de; PASSINI, Elza Yasuko. O espaço geográfico: ensino e representação. 12. ed. São Paulo: Contexto, 2002.

AMANTE, Lúcia; MORGADO, Lina. Metodologia de concepção e desenvolvimento de aplicações educativas: o caso dos materiais hipermídia. Discursos, Universidade Aberta, III Série, pp.125-138, 2001. 
BEHAR, Patrícia Alejandra et al. Objetos de aprendizagem para a educação a distância. In: BEHAR, Patricia Alejandra (Org.). Modelos pedagógicos em educação a distância. Porto Alegre: Artmed, 2009. p. 66-92.

BOOF, Leonardo. A águia e a galinha: uma metáfora da condição humana. 40. ed. Rio de Janeiro: Vozes, 1997.

ARRIÈRE, Jean. Spatial cartographic literacy and the atlas of Québec Project. In: CONFERENCE ON DISCOVERING BASIC CONCEPTS. 1999, Montreal. Anais. Acesso em: 17 mar. 2012. Disponivel em: <http://lazarus.elte.hu/ccc/10years/ea/jean1.pdf>.

CASTROGIOVANNI, Antonio Carlos (Org.). Ensino de Geografia: práticas e textualizações no cotidiano. 6. ed. Porto Alegre: Mediação, 2008.

PREECE, Jennifer; ROGERS, Yvonne; SHARP, Helen. Design de interação: além da interação homem-computador. Porto Alegre: Artmed, 2002.

SANTOS, Milton. Técnica, espaço, tempo: globalização e meio técnico-científicoinformacional. 3. ed. São Paulo: HUCITEC, 1997.

SECRETARIA DE EDUCAÇÃO FUNDAMENTAL. Parâmetros Curriculares Nacionais. Terceiro ao Quarto Ciclos do Ensino Fundamental - Geografia, Brasília: MEC/SEF, 1998.

SIMIELLI, Maria Elena Ramos. Cartografia no ensino fundamental e médio. In: Carlos, Ana Fani Alessandri (Org.). A Geografia na sala de aula. 5 ed. São Paulo: Contexto, 2003.

SOARES, Maria do Carmo Silva; KURKDJIAN, Maria de Lourdes Neves de Oliveira; MANTOVANI, Angélica C. Di Maio. Cartographic initiation for Young students, using aerial photographs and satellite images. International Archives of Photogrammetry and Remote Sensing. vol. 33, p. $84-91,2000$.

\section{Correspondência:}

\section{Gabriela Dambrós}

E-mail: gabbydambros@yahoo.com.br

Recebido em 17 de janeiro de 2012.

Revisado pelo autor em 13 de agosto de 2012.

Aceito para publicação em 03 de setembro de 2012. 